Boise State University

ScholarWorks

7-1-2011

\title{
Propagule Pressure and Introduction Pathways of Bromus Tectorum (Cheatgrass; Poaceae) in the Central United States
}

Temsha D. Huttanus

Boise State University

Richard N. Mack

Washington State University

Stephen J. Novak

Boise State University 
Int. J. Plant Sci. 172(6):783-794. 2011.

(c) 2011 by The University of Chicago. All rights reserved.

1058-5893/2011/17206-0004\$15.00 DOI: $10.1086 / 660107$

\title{
PROPAGULE PRESSURE AND INTRODUCTION PATHWAYS OF BROMUS TECTORUM (CHEATGRASS; POACEAE) IN THE CENTRAL UNITED STATES
}

\author{
Temsha D. Huttanus, * Richard N. Mack, † and Stephen J. Novak ${ }^{1, *}$ \\ *Department of Biological Sciences, Boise State University, 1910 University Drive, Boise, Idaho 83725-1515, U.S.A.; \\ and + School of Biological Sciences, Washington State University, Pullman, Washington 99164, U.S.A.
}

An introduced species' propagule pressure strongly influences the genetic diversity and evolutionary potential of its descendants and even the likelihood of biological invasion. We examined population genetic consequences arising from introduction of the invasive annual grass Bromus tectorum into the central United States (U.S.). The origin and frequency of introductions were investigated by assembling allozyme diversity data from 60 widely spaced populations. At least five introduction events contributed to the grass's genetic diversity in the central U.S. Populations in this region have fewer alleles (30 vs. 43$)$ and polymorphic loci (5 vs. 13) than native populations, evidence of a genetic bottleneck. However, the populations are, on average, more genetically diverse and less structured than native populations. Assembly within central U.S. populations of previously allopatric genotypes may have allowed the formation, via outcrossing, of a rare multilocus genotype. Genetic admixtures may have occurred through any combination of east-to-west spread coincident with nineteenth-century arrival of European settlers, dispersal from southern Ontario via Great Lakes shipping and commerce, and direct introduction from the native range. Our results illustrate the population genetic consequences of relatively high propagule pressure (i.e., repeated immigrations to a new range from multiple sources).

Keywords: allozyme diversity, biological invasion, genetic admixture, genetic bottleneck, multilocus genotype, multiple introductions.

Online enhancement: appendix table.

\section{Introduction}

Humans, through transport, international commerce and their own migrations, have accidentally or deliberately contributed to the dispersal of organisms around the globe (Ridley 1930; Lindroth 1957; Ruiz and Carlton 2003). In a minority of cases (Williamson and Fitter 1996), descendants of these immigrants become naturalized; in even fewer instances, the descendants become invaders (sensu Mack et al. 2000; Colautti and MacIssac 2004). Given the enormous damage that invasive species can wreak (Wilcove et al. 1998; Sala et al. 2000; Pimentel at al. 2005), interest has long focused on the epidemiology of invasions for clues to predicting (and thereby curbing if not preventing outright) future invasions (Mack 1996; Rejmánek et al. 2005; Richardson and Pyšek 2006). Propagule pressure, defined as the number of individuals in a propagule (propagule size), the rate at which propagules arrive per unit time (propagule number), or both (sensu Simberloff 2009), has emerged as an important predictor of establishment and the likelihood of invasion (Kolar and Lodge 2001; Lockwood et al. 2005; von Holle and Simberloff 2005; Colautti et al. 2006; Hayes and Barry 2008).

\footnotetext{
${ }^{1}$ Author for correspondence; e-mail: snovak@boisestate.edu.
}

Manuscript received December 2010; revised manuscript received March 2011.
High propagule pressure, formed by large founder populations, multiple introduction events, or both, can buffer the introduced species from the influence of detrimental stochastic events during all phases of the invasion (Mack 2000). Propagule pressure not only holds demographic and ecological consequences for plant introductions but can also have genetic consequences (Ficetola et al. 2008; Simberloff 2009; Gonçalves da Silva et al. 2010). Although propagule pressure is often viewed in terms of long-distance (intercontinental) dispersal, it can also affect range expansion during biological invasions (Lockwood et al. 2005; Colautti et al. 2006). Consequently, propagule pressure can influence the progression and genetic distribution of an invasion through the direct introduction of individuals from the donor range and the subsequent spread of genotypes during new range expansion. These events leave genetic signatures, i.e., population genetic evidence, and their relative contribution to an invasion can be evaluated through comprehensive population analyses (Squirrell et al. 2001; Muirhead et al. 2008; Novak and Rausch 2009; Novak 2011). We examined this evidence for the invader Bromus tectorum L. in reconstructing its introduction and spread in the central United States (U.S.), i.e., the region between the Appalachian Mountains and the Mississippi River.

Bromus tectorum (cheatgrass, downy brome) is a diploid $(2 \mathrm{n}=14)$, predominantly cleistogamous, annual grass (McKone 1985; Upadhyaya et al. 1986). Its native range encompasses 
most of Europe, the northern rim of Africa, and central Asia (Pierson and Mack 1990). It has been introduced widely and repeatedly into temperate regions, including Argentina, Australia, Chile, Japan, New Zealand, and North America (Mack 1981; Upadhyaya et al. 1986). The grass was most likely introduced accidentally along the eastern seaboard of the U.S. during pre-1800 European settlement (Muhlenberg 1793; Mack 1981; Bartlett et al. 2002). In western North America, the plant was first discovered at Spences Bridge, British Columbia, in 1889 (Valliant et al. 2007), and in the following decades it spread rapidly and is now the region's most abundant vascular plant (Mack 1981; Upadhyaya et al. 1986). In the western U.S., the distribution of B. tectorum continues to expand into both higher elevations and desert shrublands (Ramakrishnan et al. 2006; Kao et al. 2008). Across the midcontinent of the U.S., B. tectorum was reported as "common" throughout much of the early twentieth century; however, since $\sim 1950$, the invasion of the grass in this region appears to have accelerated (Schachner et al. 2008). Range expansion of $B$. tectorum in its new range in North America has been facilitated by varied modes and pathways (e.g., livestock, agriculture, and road and railroad development; Longman and Smith 1936; Mack 1981; Yensen 1981).

As part of our ongoing effort to reconstruct the invasion of B. tectorum in North America using genetic markers, we have analyzed 51 native and 192 North American populations of the grass. The genetic diversity of the populations analyzed to date is low in comparison to that of other diploid seed plants (Novak et al. 1991; Novak and Mack 1993; Bartlett et al. 2002; Valliant et al. 2007; Schachner et al. 2008). Across invasive populations, fewer alleles and polymorphic loci are detected than in native populations, providing evidence of founder effects associated with the species' introduction into North America. In contrast, the level of genetic diversity within introduced populations is, on average, higher and genetic differentiation among introduced populations is lower than those reported for native populations (values summarized in Valliant et al. 2007). This pattern may stem from multiple introductions into North America (i.e., a high propagule number; Novak et al. 1993; Novak and Mack 2001, 2005), as well as the spread of genotypes from previously established introduced populations during range expansion. A minimum of six or seven independent introductions of the grass occurred in the western U.S., two or three separate introductions may have occurred in the eastern U.S., and the number of introductions into Canada and the midcontinent region of the U.S. are somewhat intermediate to those for the other two regions. In addition, one multilocus genotype, Pgm-1a \& Pgm-2a, occurs to varying degrees across North America (Novak et al. 1993; Novak and Mack 2001; Bartlett et al. 2002; Valliant et al. 2007; Schachner et al. 2008), suggesting that in the U.S. this genotype could have been spread during range expansion, most probably from eastern populations with European settlers.

Determining whether the distribution of B. tectorum in North America is the product of introductions directly from the native range, of spread from other introduced populations (e.g., eastern populations), or of a combination of both is hampered by a lack of comprehensive population sampling in the central U.S., a region located between previ- ously sampled populations in the eastern U.S., southern Ontario, and the midcontinent region of the U.S. In this study, we used enzyme electrophoresis to assess the population genetic and evolutionary consequences of the introduction and spread of B. tectorum in the central U.S. Specifically, we determined the genetic diversity and structure within and among populations. Given the prominent historical transportation and economic links of the central U.S., we sought to identify (1) the extent to which the distribution of B. tectorum genotypes provides evidence of multiple introductions, a proxy for propagule number and (2) possible introduction pathways of genotypes from the native range into (and within) this region.

\section{Material and Methods}

\section{Plant Collections}

Mature panicles were collected from Bromus tectorum in 58 populations in 11 states in the central U.S. (Alabama, Illinois, Indiana, Kentucky, Michigan, Mississippi, Ohio, Pennsylvania, Tennessee, Wisconsin, and West Virginia) in June 2005; two other populations (Seney and Grand Rapids, Michigan) were sampled in July 2007. Care was taken to sample populations at or near sites of first-detection records in the region (from the dates of herbarium specimens of B. tectorum; R. N. Mack, unpublished data) as well as to sample comprehensively across the region (see Bartlett et al. 2002; Valliant et al. 2007; Schachner et al. 2008; fig. 1). Most collection sites were along roadsides or abandoned railroad tracks, near grain elevators, or in vacant lots (table A1 in the online edition of the International Journal of Plant Sciences). At each locality, 30-35 plants 1-3 m apart were sampled haphazardly. Adequate spacing between collected plants reduces the likelihood of collecting full siblings. In populations with fewer than 30 individuals, the panicles from all individuals were collected. Panicles were stored at room temperature in individually labeled paper envelopes.

\section{Enzyme Electrophoresis}

Caryopses were germinated at room temperature in petri dishes lined with moistened filter paper. Approximately 7-10 d after germination, when the seedlings were $3-10 \mathrm{~cm}$ tall, they were harvested and macerated in a tris- $\mathrm{HCl}$ grinding buffer-PVP solution. Starch concentration in the gels was $12 \%(\mathrm{w} / \mathrm{v})$. Enzyme electrophoresis procedures generally followed those of Soltis et al. (1983), with modifications described by Novak et al. (1991). The 15 enzymes employed here were visualized with four buffer systems: isocitrate dehydrogenase, glucose-6-phosphate dehydrogenase, and shikimate dehydrogenase with system 1 of Soltis et al. (1983); alcohol dehydrogenase, aldolase, glutamate dehydrogenase, and phosphoglucoisomerase with system 6; glutamate oxalacetate transaminase, leucine aminopeptidase, malic enzyme, superoxide dismutase, and triosephosphate isomerase with system 8; and malate dehydrogenase, phosphoglucomutase, and 6-phosphogluconate dehydrogenase with system 9 .

Nomenclature for the resulting 25 loci and all alleles follows that of Novak and Mack (1993). Multilocus genotype 


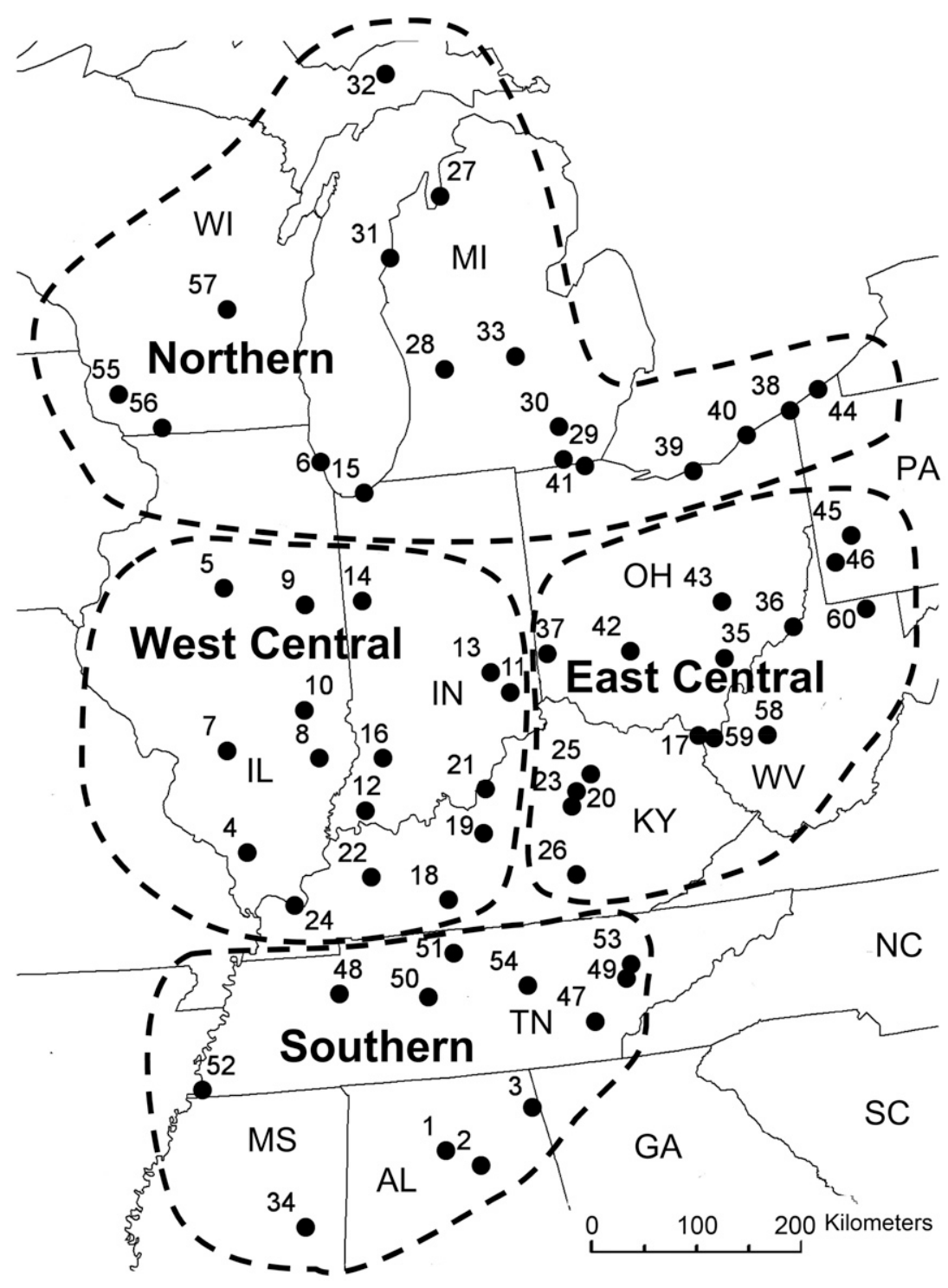

Fig. 1 Locations of the 60 populations of Bromus tectorum from the central United States analyzed in this study. Numbers correspond to the population designations and locations in table 2. Postal code abbreviations are used for states. Each population was assigned to one of four geographic subregions, as described in the text: Northern, East Central, West Central, and Southern.

designations are based on the identity of the allele at each locus. The most common genotype (MCG) refers to the most common combination of alleles at the 25 loci. The MCG has the highest frequency of occurrence across both native and introduced populations of B. tectorum (Novak 1990; Valliant et al. 2007; Schachner et al. 2008). Other multilocus genotypes were determined by specific alleles that deviate from the MCG at one or more loci.

\section{Data Analysis}

Allozyme data were analyzed with BIOSYS-1 (Swofford and Selander 1981) in order to determine the level and structure of genetic diversity within and among populations of $B$. tectorum in the central U.S. This procedure ensures that the same parameters were used to compare genetic diversity in central U.S. populations with results previously reported for B. tectorum in Eurasia (Novak and Mack 1993) and North America (Novak et al. 1991; Bartlett et al. 2002; Valliant et al. 2007; Schachner et al. 2008). Allozyme data were entered into BIOSYS-1 as genotype frequencies with populations arranged hierarchically (four subregions) on the basis of geographic location (fig. 1). Genetic diversity in B. tectorum was expressed as the mean number of alleles per locus $(A)$, the percentage of polymorphic loci per population under the $99 \%$ criterion $(\% P)$, the expected mean heterozygosity $\left(H_{\text {exp }}\right)$, and the mean observed heterozygosity $\left(H_{\text {obs }}\right)$. Expected mean heterozygosity was computed with the unbiased-estimate method of Nei (1978). Mean observed heterozygosity was determined by the direct-count method. Means of these geneticdiversity parameters were used to describe the overall diversity within populations from the central U.S. 
Values for Wright's fixation index $(F)$ at each polymorphic locus within all populations were calculated as the ratio of observed to expected heterozygotes, $F=1-\left(H_{\mathrm{obs}} / H_{\text {exp }}\right)$ (Wright 1965). The significance of any deviation of $H_{\mathrm{obs}}$ from $H_{\text {exp }}$ was determined with a $\chi^{2}$ test (Workman and Niswander 1970).

Nei's $(1973,1977)$ gene diversity statistics were used to partition total allelic diversity within and among populations, with the variance components from the output of the Wright78 analysis of BIOSYS-1 (Swofford and Selander 1981). At each polymorphic locus, the total allelic diversity $\left(H_{\mathrm{T}}\right)$ was partitioned into a within-population component $\left(H_{\mathrm{S}}\right)$ and an among-populations component $\left(D_{\mathrm{ST}}\right): H_{\mathrm{T}}=H_{\mathrm{S}}+D_{\mathrm{ST}}$. The proportion of genetic diversity partitioned among populations $\left(G_{\mathrm{ST}}\right)$ was determined as $G_{\mathrm{ST}}=D_{\mathrm{ST}} H_{\mathrm{T}}$. Means of Nei's gene diversity statistics from all polymorphic loci were employed to describe the overall allocation of allelic diversity within and among populations for the study region. Nei's (1978) unbiased genetic-identity coefficients $(I)$ were calculated with BIOSYS-1 for all possible pairwise comparisons among all central U.S. populations. The unweighted pair-group method with arithmetic averaging (UPGMA) algorithm (Swofford and Selander 1981) was used to generate a phenogram for these 60 populations of $B$. tectorum on the basis of genetic-identity (I) values.

\section{Results}

Genetic Diversity of Bromus tectorum in the Central U.S.

Estimates of the genetic diversity and structure of central U.S. populations of B. tectorum are based on an average of 31.75 individuals per population $(94.8 \%$ germination of all caryopses collected). Among the 60 populations, 30 alleles were detected ( 1.20 alleles/locus) at the 25 loci surveyed; five loci $(20 \%)$ are polymorphic: Got-4, Mdh-2, Mdh-3, Pgm-1, and Pgm-2 (table 1). Each polymorphic locus has two alleles.
The remaining 20 loci are monomorphic: their alleles do not differ from those of the MCG. When polymorphic, $M d h-2$ and $M d h-3$ display the same allele frequencies in each population; a similar pattern was detected for Pgm-1 and Pgm-2 (table 1). Although these pairs of loci have the same frequencies in populations from the central U.S., this is not true across all populations of B. tectorum that we have analyzed (S. J. Novak and R. N. Mack, unpublished data). Thus, we do not believe that this pattern indicates that these loci are physically linked on the same chromosome. Rather, this pattern is most likely due to gametic phase disequilibrium, which can be generated in populations during demographic processes, such as founder events, and maintained by high rates of selfing (see FlintGarcia et al. 2003). Across the entire study region, the Pgm$1 a$ and Pgm-2a alleles were detected in populations from all four subregions: 34 of $60(56.7 \%)$ populations, with a mean frequency of 0.288 (fig. 2; table 1). The $M d h-2 b$ and $M d b-3 b$ alleles occur in five of $60(8.3 \%)$ populations, with a mean frequency of 0.026 ; Got-4c was detected in three of $60(5 \%)$ populations, with a mean frequency of 0.007 .

Slightly more than half ( 32 of $60,53.3 \%$ ) of the populations from the central U.S. are genetically polymorphic (exhibit multiple alleles), while the remaining 28 populations are monomorphic at the 25 scored loci (fig. 2; table 2). On average, the 60 populations that we examined display 1.05 alleles per locus $(A)$. Values for $\% P$ range from 0 to 20 , with an average of 4.7 per population. The population at Jasper, Michigan (MI), contained the highest level of within-population genetic diversity: 1.20 alleles per locus and five polymorphic loci $(\% P=20.0$; table 2$)$. Populations at Olney, Illinois (IL), and Porter Reach, Indiana (IN), are polymorphic at four loci $(A=1.16, \% P=16.0)$, while the population from Athens, Tennessee (TN), is polymorphic at three loci $(A=1.12$, $\% P=12.0)$. Across all 60 populations, the expected mean heterozygosity $\left(H_{\text {exp }}\right)$, which is equivalent to the expected genetic diversity within populations, is 0.014 (table 2). The highest value of $H_{\exp }$ was detected in the Olney, IL, population

Table 1

Mean Allele Frequencies for All Polymorphic Loci for 60 Populations of Bromus tectorum from the Central United States That Vary Relative to the Most Common Genotype (MCG)

\begin{tabular}{|c|c|c|c|c|c|c|}
\hline Locus, allele & MCG & Northern (17) & Southern (12) & East Central (15) & West Central (16) & All 60 populations \\
\hline \multicolumn{7}{|l|}{ Got-4: } \\
\hline$b$ & 1.000 & $.998(17)$ & $.994(12)$ & $.980(15)$ & 1.000 & $.993(60)$ \\
\hline$c$ & .000 & $.002(1)$ & $.006(1)$ & $.020(1)$ & .000 & .007 (3) \\
\hline \multicolumn{7}{|l|}{$M d h-2:$} \\
\hline$a$ & 1.000 & $.996(17)$ & 1.000 & 1.000 & $.906(15)$ & $.974(59)$ \\
\hline$b$ & .000 & $.004(2)$ & .000 & .000 & $.094(3)$ & $.026(5)$ \\
\hline \multicolumn{7}{|l|}{$M d h-3:$} \\
\hline$a$ & 1.000 & $.996(17)$ & 1.000 & 1.000 & $.906(15)$ & $.974(59)$ \\
\hline$b$ & .000 & $.004(2)$ & .000 & .000 & $.094(3)$ & $.026(5)$ \\
\hline \multicolumn{7}{|l|}{ Pgm-1: } \\
\hline$a$ & .000 & $.240(8)$ & $.464(9)$ & $.245(8)$ & $.246(9)$ & $.288(34)$ \\
\hline$b$ & 1.000 & $.760(17)$ & $.536(10)$ & $.755(14)$ & $.754(16)$ & $.712(57)$ \\
\hline \multicolumn{7}{|l|}{ Pgm-2: } \\
\hline a & .000 & $.240(8)$ & $.464(9)$ & $.245(8)$ & $.246(9)$ & $.288(34)$ \\
\hline$b$ & 1.000 & $.760(17)$ & $.536(10)$ & $.755(14)$ & $.754(16)$ & $.712(57)$ \\
\hline
\end{tabular}

Note. The number of populations within each subregion of the central United States is given in parentheses. Numbers in parentheses beside the allele frequencies are the number of populations in each subregion, or across the entire region, that possess that allele. 


\section{GENOTYPE}

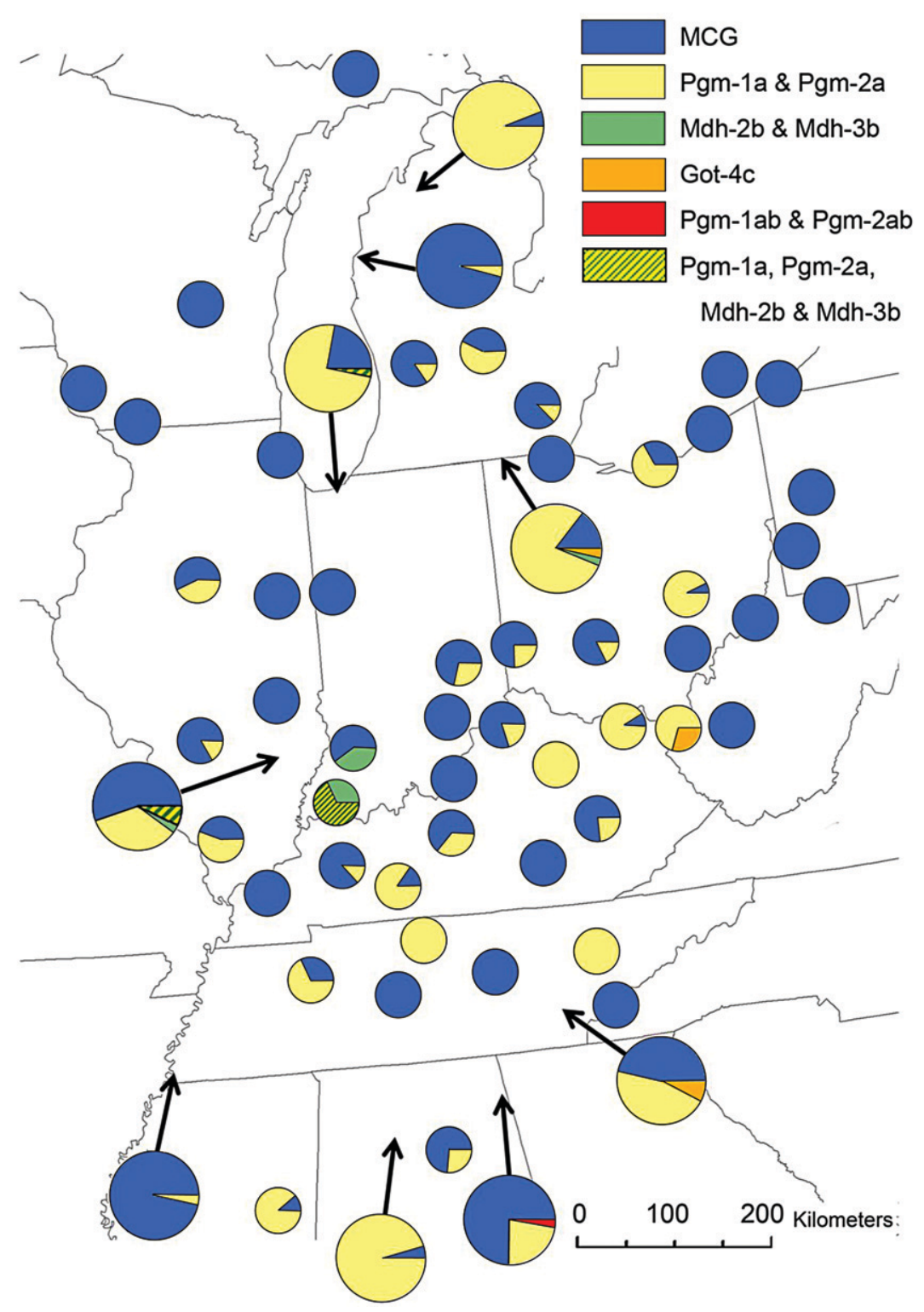

Fig. 2 Multilocus genotype distributions within each of the 60 populations of Bromus tectorum from the central United States. The size of some of the pie charts in this figure was increased only to improve their readability. Arrows accompanying these pie charts indicate the geographic locations of the populations.

$\left(H_{\exp }=0.056\right)$, and the lowest value for a population with polymorphic loci was detected in Memphis, TN $\left(H_{\exp }=0.005\right)$.

The mean observed heterozygosity $\left(H_{\mathrm{obs}}\right)$ for all 60 populations is 0.00003 (table 2). We detected only one heterozygote: one individual in Valley Head, Alabama, was heterozygous at both Pgm-1 and Pgm-2. This plant appeared to be the progeny of a heterozygous maternal plant, and by convention we report the results of the first individual analyzed in any progeny array. A total of 71 polymorphic loci were detected across the 60 central U.S. populations that we analyzed. Wright's fixation index $(F)$ is 1.0 for 69 of these 71 loci (data not shown), indicating complete deviation from Hardy-Weinberg equilibrium.
The fixation indices at Pgm-1 and Pgm-2 in the population from Valley Head are both 0.922. Consequently, significant heterozygote deficiencies $(P<0.001)$ were detected at every polymorphic locus in all these populations (data not shown).

\section{Population Differentiation of Bromus tectorum in the Central U.S.}

The loci Pgm-1 and Pgm-2 are the most polymorphic among all populations in the region (table 1; fig. 2), and consequently, these loci have the highest value for total gene (allelic) diversity $\left(H_{\mathrm{T}}=0.410\right.$; table 3$)$. The among-population 
component for Pgm-1 and Pgm-2 $\left(D_{\mathrm{ST}}=0.249\right)$ was larger than the within-population component $\left(H_{S}=0.161\right)$; thus, the proportion of the total gene diversity partitioned among populations $\left(G_{\mathrm{ST}}\right)$ is 0.607 at both loci. Even more of the total gene diversity at the loci $M d h-2$ and $M d h-3$ is partitioned among populations $\left(G_{\mathrm{ST}}=0.739\right)$. Got-4 displays the lowest value for total gene diversity $\left(H_{\mathrm{T}}=0.013\right)$ and is the only polymorphic locus with a within-population component of diversity greater than its among-population component. Consequently, the value of $G_{\mathrm{ST}}$ at Got-4 is 0.216 . The mean value of $H_{\mathrm{T}}$ for all polymorphic loci is 0.187 , and the mean value of $G_{\mathrm{ST}}$ is 0.582 , indicating that most of the genetic diversity $(58.2 \%)$ for all 60 populations was partitioned among populations (table 3 ).

The mean value of Nei's (1978) unbiased genetic identity coefficient for all possible pairwise population comparisons is $I=0.976$ (data not shown), indicating a high level of genetic similarity among populations of $B$. tectorum in the study region. For instance, the MCG was detected in populations from all subregions; consequently, all intra- and interregional comparisons include population pairs with $I=1.000$ (table 4). The mean values of all pairwise population com- parisons that include populations from the southern subregion are among the lowest, probably because of the high frequency of $P g m-1 a$ and $P g m-2 a$ in the southern subregion's populations.

The UPGMA cluster diagram based on Nei's (1978) I values provides a graphic representation of the high level of genetic similarity among populations in the central U.S. (fig. $3)$. Genotypes of 27 of the 60 populations form the same cluster: these populations are either fixed for or had a high frequency of the MCG. Other clusters are defined mainly by different allelic variants. For instance, the position of the Daylight-Earle, IN, population in the cluster diagram reflects the fixation of $M d h-2 b$ and $M d h-3 b$ and the high frequency of Pgm-1a and Pgm-2a in this population.

\section{Discussion}

\section{Estimating Propagule Pressure}

Determining the propagule pressure that leads to a biological invasion ideally involves knowing the number of founders and/or the number of founder events in a new range

Table 2

Measures of Genetic Diversity for 60 Populations of Bromus tectorum from the Central United States

\begin{tabular}{|c|c|c|c|c|c|c|c|c|c|c|c|}
\hline Population no., locality & $N$ & $A$ & $\% P$ & $H_{\exp }$ & $H_{\mathrm{obs}}$ & Population no., locality & $N$ & $A$ & $\% P$ & $H_{\exp }$ & $H_{\mathrm{obs}}$ \\
\hline 1. Cullman, $\mathrm{AL}^{\mathrm{a}}$ & 26 & 1.08 & 8.0 & .006 & .000 & 32. Seney, MI & 30 & 1.00 & .0 & .000 & .000 \\
\hline 2. Tait's Gap, $\mathrm{AL}^{\mathrm{a}}$ & 33 & 1.08 & 8.0 & .034 & .000 & 33. St. Johns, $\mathrm{MI}^{\mathrm{a}}$ & 28 & 1.08 & 8.0 & .040 & .000 \\
\hline 3. Valley Head, $\mathrm{AL}^{\mathrm{a}}$ & 35 & 1.08 & 8.0 & .030 & $.002^{\mathrm{b}}$ & 34. Starkville, $\mathrm{MS}^{\mathrm{a}}$ & 35 & 1.08 & 8.0 & .016 & .000 \\
\hline 4. Carbondale, $\mathrm{IL}^{\mathrm{a}}$ & 29 & 1.08 & 8.0 & .040 & .000 & 35. Athens, $\mathrm{OH}$ & 35 & 1.00 & .0 & .000 & .000 \\
\hline 5. Eureka, $\mathrm{IL}^{\mathrm{a}}$ & 33 & 1.08 & 8.0 & .040 & .000 & 36. Belmont, OH & 32 & 1.00 & .0 & .000 & .000 \\
\hline 6. Evanston, IL & 33 & 1.00 & .0 & .000 & .000 & 37. Camden, $\mathrm{OH}^{\mathrm{a}}$ & 41 & 1.08 & 8.0 & .030 & .000 \\
\hline 7. Greenville, $\mathrm{IL}^{\mathrm{a}}$ & 35 & 1.08 & 8.0 & .023 & .000 & 38. Conneaut, $\mathrm{OH}$ & 32 & 1.00 & .0 & .000 & .000 \\
\hline 8. Olney, $\mathrm{IL}^{\mathrm{a}}$ & 29 & 1.16 & 16.0 & .056 & .000 & 39. Lorain, $\mathrm{OH}^{\mathrm{a}}$ & 24 & 1.08 & 8.0 & .036 & .000 \\
\hline 9. Paxton, IL & 35 & 1.00 & .0 & .000 & .000 & 40. Painesville, $\mathrm{OH}$ & 35 & 1.00 & .0 & .000 & .000 \\
\hline 10. Toledo, IL & 31 & 1.00 & .0 & .000 & .000 & 41. Toledo, $\mathrm{OH}$ & 34 & 1.00 & .0 & .000 & .000 \\
\hline 11. Ballstown, IN & 35 & 1.00 & .0 & .000 & .000 & 42. Washington Court House, $\mathrm{OH}^{\mathrm{a}}$ & 35 & 1.08 & 8.0 & .023 & .000 \\
\hline 12. Daylight-Earle, $\mathrm{IN}^{\mathrm{a}}$ & 35 & 1.08 & 8.0 & .035 & .000 & 43. Zanesville, $\mathrm{OH}^{\mathrm{a}}$ & 26 & 1.08 & 8.0 & .012 & .000 \\
\hline 13. Hendricks Township School, $\mathrm{IN}^{\mathrm{a}}$ & 35 & 1.08 & 8.0 & .033 & .000 & 44. Erie County, PA & 31 & 1.00 & .0 & .000 & .000 \\
\hline 14. Pine Village, IN & 33 & 1.00 & .0 & .000 & .000 & 45. Pittsburgh, PA & 30 & 1.00 & .0 & .000 & .000 \\
\hline 15. Porter Reach, IN ${ }^{\mathrm{a}}$ & 32 & 1.16 & 16.0 & .033 & .000 & 46. Washington, PA & 38 & 1.00 & .0 & .000 & .000 \\
\hline 16. Washington, $\mathrm{IN}^{\mathrm{a}}$ & 30 & 1.08 & 8.0 & .039 & .000 & 47. Athens, $\mathrm{TN}^{\mathrm{a}}$ & 26 & 1.12 & 12.0 & .046 & .000 \\
\hline 17. Ashland, KY ${ }^{\mathrm{a}}$ & 34 & 1.08 & 8.0 & .013 & .000 & 48. Camden, $\mathrm{TN}^{\mathrm{a}}$ & 34 & 1.08 & 8.0 & .036 & .000 \\
\hline 18. Bowling Green, $K Y^{\mathrm{a}}$ & 32 & 1.08 & 8.0 & .021 & .000 & 49. Farragut, TN & 32 & 1.00 & .0 & .000 & .000 \\
\hline 19. Elizabethtown, KY ${ }^{\mathrm{a}}$ & 28 & 1.08 & 8.0 & .037 & .000 & 50. Franklin, TN & 25 & 1.00 & .0 & .000 & .000 \\
\hline 20. Lexington-Fayette, $\mathrm{KY}^{\mathrm{a}}$ & 35 & 1.08 & 8.0 & .026 & .000 & 51. Gallatin, TN & 29 & 1.00 & .0 & .000 & .000 \\
\hline 21. Louisville, KY & 35 & 1.00 & .0 & .000 & .000 & 52. Memphis, $\mathrm{TN}^{\mathrm{a}}$ & 30 & 1.08 & 8.0 & .005 & .000 \\
\hline 22. Madisonville, KY $\mathrm{K}^{\mathrm{a}}$ & 30 & 1.08 & 8.0 & .019 & .000 & 53. Powell, TN & 35 & 1.00 & .0 & .000 & .000 \\
\hline 23. Nicholasville, $\mathrm{KY}^{\mathrm{a}}$ & 39 & 1.08 & 8.0 & .029 & .000 & 54. Sparta, TN & 35 & 1.00 & .0 & .000 & .000 \\
\hline 24. Paducah, KY & 31 & 1.00 & .0 & .000 & .000 & 55. Fennimore, WI & 30 & 1.00 & .0 & .000 & .000 \\
\hline 25. Paris, KY & 35 & 1.00 & .0 & .000 & .000 & 56. Gratiot, WI & 32 & 1.00 & .0 & .000 & .000 \\
\hline 26. Somerset, KY & 32 & 1.00 & .0 & .000 & .000 & 57. Ripon, WI & 23 & 1.00 & .0 & .000 & .000 \\
\hline 27. Elk Rapids, $\mathrm{MI}^{\mathrm{a}}$ & 19 & 1.08 & 8.0 & .008 & .000 & 58. Charleston, WV & 35 & 1.00 & .0 & .000 & .000 \\
\hline 28. Grand Rapids, $\mathrm{MI}^{\mathrm{a}}$ & 26 & 1.08 & 8.0 & .021 & .000 & 59. Huntington, $\mathrm{WV}^{\mathrm{a}}$ & 34 & 1.04 & 4.0 & .017 & .000 \\
\hline 29. Jasper, $\mathrm{MI}^{\mathrm{a}}$ & 34 & 1.20 & 20.0 & .034 & .000 & 60. Morgantown, WV & 35 & 1.00 & .0 & .000 & .000 \\
\hline 30. Manchester, $\mathrm{MI}^{\mathrm{a}}$ & 32 & 1.08 & 8.0 & .018 & .000 & Mean & 31.75 & 1.05 & 4.73 & .014 & .00003 \\
\hline 31. Manistee, $\mathrm{MI}^{\mathrm{a}}$ & 23 & 1.08 & 8.0 & .007 & .000 & & & & & & \\
\hline
\end{tabular}

Note. $\quad N=$ number of individuals sampled in each population; $A=$ mean number of alleles per locus; $\% P=$ percentage of polymorphic loci; $H_{\exp }=$ expected mean heterozygosity; $H_{\text {obs }}=$ mean observed heterozygosity.

${ }^{\text {a }}$ Central U.S. populations of B. tectorum that possess genetic diversity.

${ }^{\mathrm{b}}$ This population was the only one from the central United States in which heterozygosity was observed. 


\section{Table 3}

Nei's $(1973,1977)$ Gene Diversity Statistics for 60 Populations of Bromus tectorum from the Central United States

\begin{tabular}{lllll}
\hline Locus & $H_{\mathrm{T}}$ & $H_{\mathrm{S}}$ & $D_{\mathrm{ST}}$ & $G_{\mathrm{ST}}$ \\
\hline Got-4 & .013 & .010 & .003 & .216 \\
Mdh-2 & .051 & .013 & .038 & .739 \\
Mdh-3 & .051 & .013 & .038 & .739 \\
Pgm-1 & .410 & .161 & .249 & .607 \\
Pgm-2 & .410 & .161 & .249 & .607 \\
Mean & .187 & .072 & .115 & .582 \\
\hline
\end{tabular}

Note. $H_{\mathrm{T}}=$ total gene diversity; $H_{\mathrm{S}}=$ within-population component; $D_{\mathrm{ST}}=$ among-populations component; $G_{\mathrm{ST}}=$ proportion of total genetic diversity partitioned across the populations.

(Lockwood et al. 2005; Simberloff 2009). This information is most often available in the extraordinarily detailed records for many bird introductions (Long 1981 and references therein; Veltman et al. 1996) but is progressively less available for mammals (Layne 1997), insects (Simberloff 1986), and plants (Lyon 1927). For accidentally introduced plants, it is unlikely that information on the number of founders and/or the number of founder events has ever been recorded.

Alternatively, propagule pressure can be estimated with molecular genetic data (Ficetola et al. 2008; Ross and Shoemaker 2008; Gonçalves da Silva et al. 2010). The genetic signature of high propagule pressure can reflect several patterns of genetic diversity within and among populations (Kolbe et al. 2004; Novak and Mack 2005; Wares et al. 2005; Ficetola et al. 2008; Simberloff 2009; Gonçalves da Silva et al. 2010): (1) the number of haplotypes or multilocus genotypes of a species across its new range would likely be large; (2) levels of genetic diversity would be similar within native and introduced populations, with little evidence for genetic bottlenecks (but see Dlugosch and Parker 2008); (3) genetic admixture(s) are expected if propagule pressure results in the introduction and establishment, within the same invasive population, of two or more independently derived native genotypes; and (4) if genetic admixtures are common, native and introduced populations will have similar genetic structures. (If propagule pressure is sufficiently high, introduced populations may even have less structure than native populations.) Our genetic data for invasive populations of $B$. tectorum from the central U.S. are generally consistent with all four of these patterns.

\section{Source Populations}

Bromus tectorum is a highly selfing plant species worldwide (McKone 1985; Novak and Mack 2001). Consequently, introduced populations maintain the multilocus genotypes of their founders as genetic admixtures. As a result, probable source populations or regions in the native range can be identified when native multilocus genotypes are highly structured (Novak and Mack 2001; Novak 2011). Three of the five homozygous multilocus genotypes detected in the central U.S. have been detected in the native range. The MCG occurs across Eurasia (Novak 1990); consequently, no geographically restricted donor region can be identified. In contrast, the Pgm-1a \& Pgm-2a multilocus genotype has been detected in the native range only in populations at Vac, Hungary, and Bratislava, Slovakia (Novak and Mack 2001), but it occurs in 33 of 60 central U.S. populations (table 5). We detected the Got-4c multilocus genotype, a genotype for which the known native distribution includes Bayreuth, Germany, and Libochovice, Czech Republic (Novak and Mack 2001), in three populations in the study region. In contrast, the $M d b$ $2 b$ \& $M d h-3 b$ and $M d h-2 b, M d h-3 b, P g m-1 a$ \& Pgm- $2 a$ multilocus genotypes have yet to be detected in native Eurasian populations (table 5). On the basis of the total number of multilocus genotypes that we detected and the highly restricted distribution of these genotypes in their native range, at least five founder events apparently contributed to the genetic diversity of this invader in the central U.S.

\section{Introduction and Spread in the Central U.S.}

From the current geographic distribution of its multilocus genotypes, coupled with historical records, the introduction pathway of B. tectorum into the central U.S. may have followed, singly or in combination, any of at least three scenarios: east-to-west spread with European settlement, dispersal from southern Ontario via Great Lakes shipping and commerce, and direct introduction from the native range.

The MCG, the Pgm-1a \& Pgm-2a multilocus genotype, and the $M d h-2 b$ \& $M d h-3 b$ multilocus genotype have, with different frequencies, a transcontinental distribution in North America (Novak and Mack 1993, 2001; Bartlett et al. 2002; Valliant et al. 2007; Schachner et al. 2008). Distribution of these three genotypes in the U.S. is generally consistent with east-to-west spread. For instance, the MCG occurs with highest frequency in populations along the eastern seaboard but

\section{Table 4}

Nei's (1978) Unbiased Genetic Identity (I) Values Averaged Within and Between Population of Bromus tectorum from the Four Subregions in the Central United States

\begin{tabular}{lccccc}
\hline Region & No. populations & Northern & East Central & Southern & West Central \\
\hline Northern & 17 & $.980(.928-1.000)$ & & & \\
East Central & 15 & $.980(.920-1.000)$ & $.977(.916-1.000)$ & & \\
Southern & 12 & $.974(.920-1.000)$ & $.972(.916-1.000)$ & $.972(.920-1.000)$ & \\
West Central & 16 & $.979(.881-1.000)$ & $.977(.876-1.000)$ & $.971(.881-1.000)$ & $.976(.881-1.000)$ \\
\hline
\end{tabular}

Note. The means of all within-region pairwise comparisons appear on the diagonal, and the means of between-region comparisons appear below the diagonal. The range of genetic-identity values for population pairs appears in parentheses. 


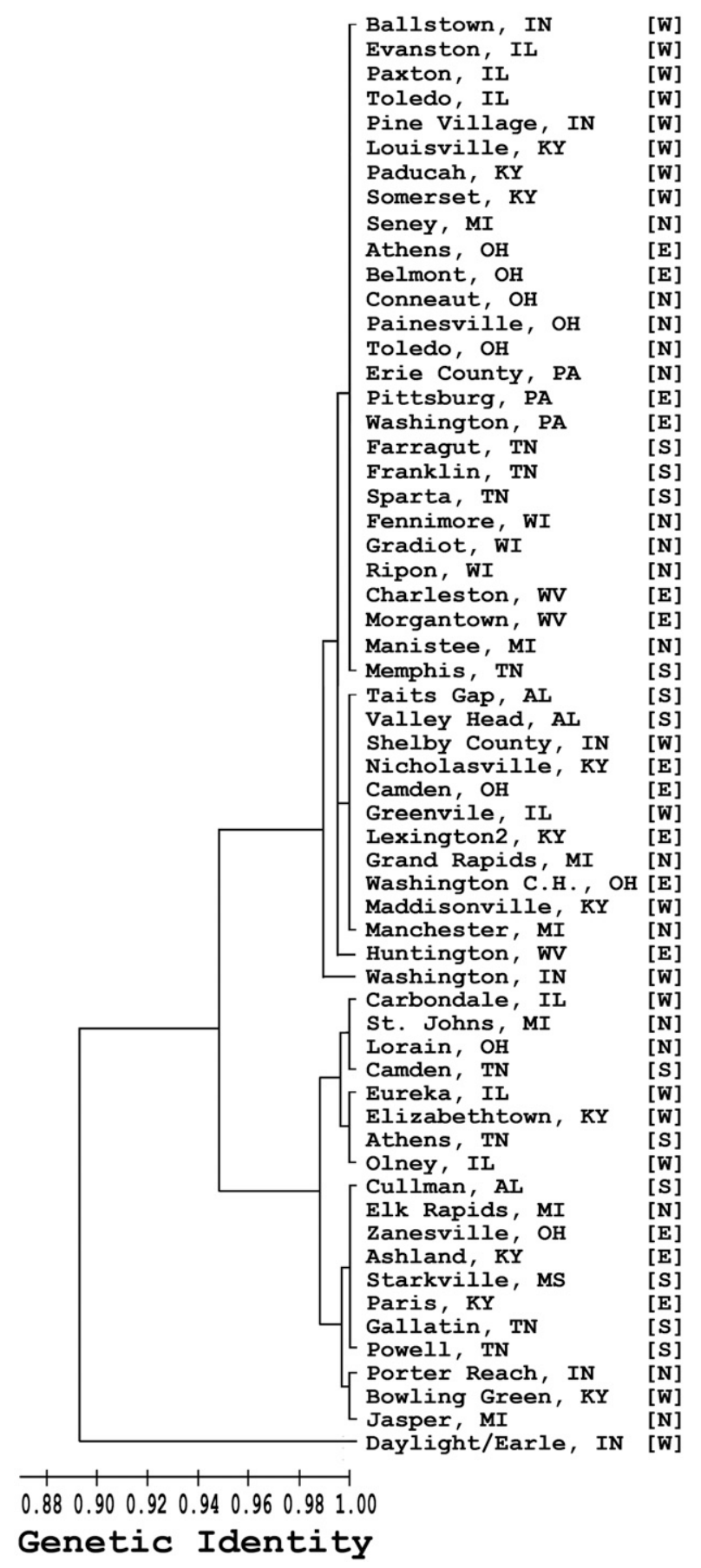

Fig. 3 Unweighted pair-group method with arithmetic averaging (UPGMA) phenogram based on Nei's (1978) unbiased genetic-identity values for the 60 populations of Bromus tectorum from the central United States. Postal code abbreviations are used for states. Letters in brackets indicate the geographic subregions to which each population was assigned as described in the text: $\mathrm{N}$ for Northern, E for East Central, W for West Central, and S for Southern.

is less common progressively westward. This pattern could have arisen from early (and likely repeated) introductions of plants with the MCG on the East Coast (Novak and Mack 2001; Bartlett et al. 2002), coupled with subsequent acciden- tal spread westward (Mack 1981; Novak and Mack 2005). Although the MCG has been detected near some early collection sites west of the Appalachian Mountains (e.g., Erie, PA, in 1884), it is currently unresolvable whether this genotype was also introduced directly into the central U.S. from Europe.

An additional (or alternative) introduction pathway for the Pgm-1a \& Pgm-2a multilocus genotype into the central U.S. may have involved Great Lakes commerce and shipping. This two-way trade has long occurred between the central U.S. and southeastern Canada (Haites et al. 1975; Cochrane 1993; Shaw 1993; Meinig 1995), and B. tectorum may have been dispersed along this route. Bromus tectorum was collected repeatedly at Great Lakes ports and nearby railroads in eastern Canada from 1880 to 1900, and the Pgm-1a \& Pgm-2a genotype is now common in southern Ontario (Valliant et al. 2007). Likewise, the Got-4c multilocus genotype, which is undetected along the U.S. East Coast (Bartlett et al. 2002), has also been detected in eastern Canada (Valliant et al. 2007) and may have entered the central U.S. from southern Ontario. The low frequency of the Got$4 c$ genotype in central U.S. populations (table 1 ) suggests low propagule pressure for its introduction and spread in the region.

The Mdh-2b, Mdh-3b, Pgm-1a \& Pgm-2a multilocus genotype, detected in three populations in our study region (fig. 2; table 5), is quite rare. It had been reported previously for only one plant, at Martin, South Dakota (Schachner et al. 2008). Schachner et al. (2008) suggested that this is a novel, recombinant multilocus genotype, although given this second occurrence, that interpretation needs reassessment. Although this genotype has not been detected among native populations (Novak and Mack 1993, 2001), it may have been introduced directly into the U.S. (e.g., near Daylight-Earle, IN) and subsequently spread. Alternatively, the $M d h-2 b, M d b$ 3b, Pgm-1a \& Pgm-2a multilocus genotype may have arisen in situ within the central U.S. Resolving the origin of this multilocus genotype requires additional sampling in the native range (Novak and Mack 1993).

\section{Genetic Diversity}

The genetic diversity of an alien species in its new range is influenced by propagule pressure (Colautti et al. 2006; Simberloff 2009; Novak 2011). Founders drawn from a restricted area within the native range may possess little of the species' genetic diversity (Tsutsui et al. 2000; Sakai et al. 2001), a situation compounded in predominantly selfpollinating species (Brown and Marshall 1981; Barrett and Richardson 1986; Barrett and Shore 1989; Novak and Mack 1993). Among the 25 scored loci, central U.S. populations of B. tectorum have fewer alleles (30 vs. 43 ) and polymorphic loci (5 vs. 13) than native populations (Novak and Mack 1993, 2005), indicating that the former have experienced genetic drift through founder events and population bottlenecks during introduction, range expansion, or both (Nei et al. 1975; Brown and Marshall 1981; Watterson 1984; Barrett and Husband 1990). Furthermore, our results are consistent with theoretical predictions of a genetic bottleneck associated with population bottlenecks or founding 
Table 5

Introduced Populations of Bromus tectorum from the Central United States and Populations from the Native Range in Eurasia That Share the Same Homozygous Multilocus Genotype

\begin{tabular}{|c|c|c|c|c|}
\hline \multirow[b]{2}{*}{ Multilocus genotype } & \multicolumn{2}{|l|}{ Central United States } & \multicolumn{2}{|l|}{ Native range } \\
\hline & Population & Frequency & Population & Frequency \\
\hline \multirow[t]{5}{*}{ Got-4c } & & & Bayreuth, Germany & 1.000 \\
\hline & & & Libochovice, Czech Republic & .222 \\
\hline & Jasper, MI & .029 & & \\
\hline & Athens, TN & .077 & & \\
\hline & Huntington, WV & .294 & & \\
\hline \multirow[t]{5}{*}{$M d h-2 b \& M d h-3 b$} & & & No match detected & \\
\hline & Olney, IL & .034 & & \\
\hline & Daylight-Earle, IN & .314 & & \\
\hline & Washington, IN & .400 & & \\
\hline & Jasper, MI & .029 & & \\
\hline \multirow[t]{4}{*}{$M d h-2 b, M d h-3 b$, Pgm-1a \& Pgm-2a } & & & No match detected & \\
\hline & Olney, IL & .069 & & \\
\hline & Daylight-Earle, IN & .686 & & \\
\hline & Porter Reach, IN & .031 & & \\
\hline \multirow[t]{35}{*}{ Pgm-1a \& Pgm-2a } & & & Vac, Hungary & .280 \\
\hline & & & Bratislava, Slovakia & .036 \\
\hline & Cullman, AL & .962 & & \\
\hline & Tait's Gap, AL & .303 & & \\
\hline & Valley Head, AL & .229 & & \\
\hline & Carbondale, IL & .552 & & \\
\hline & Eureka, IL & .424 & & \\
\hline & Greenville, IL & .171 & & \\
\hline & Olney, IL & .345 & & \\
\hline & Hendricks Township School, IN & .286 & & \\
\hline & Porter Reach, IN & .750 & & \\
\hline & Ashland, KY & .914 & & \\
\hline & Bowling Green, KY & .844 & & \\
\hline & Elizabethtown, KY & .357 & & \\
\hline & Lexington-Fayette, KY & .200 & & \\
\hline & Madisonville, $\mathrm{KY}$ & .133 & & \\
\hline & Nicholasville, KY & .231 & & \\
\hline & Paris, KY & 1.000 & & \\
\hline & Elk Rapids, MI & .947 & & \\
\hline & Grand Rapids, MI & .154 & & \\
\hline & Jasper, MI & .794 & & \\
\hline & Manchester, MI & .125 & & \\
\hline & Manistee, MI & .043 & & \\
\hline & St. Johns, MI & .571 & & \\
\hline & Starkville, MS & .886 & & \\
\hline & Camden, $\mathrm{OH}$ & .244 & & \\
\hline & Lorain, $\mathrm{OH}$ & .667 & & \\
\hline & Washington Court House, $\mathrm{OH}$ & .171 & & \\
\hline & Zanesville, $\mathrm{OH}$ & .923 & & \\
\hline & Athens, TN & .462 & & \\
\hline & Camden, TN & .676 & & \\
\hline & Gallatin, TN & 1.000 & & \\
\hline & Memphis, TN & .033 & & \\
\hline & Powell, TN & 1.000 & & \\
\hline & Huntington, WV & .706 & & \\
\hline
\end{tabular}

Note. Data for native-range populations are from Novak et al. (1993) and Novak and Mack (2001).

events (Nei et al. 1975; Watterson 1984): most of the rare alleles or multilocus genotypes of the native range, which predominantly occur in southwestern Asia and Morocco (Novak 1990; Novak and Mack 1993), were not detected in these central U.S. populations.
Despite low genetic diversity across populations, genetic diversity within populations in the central U.S. was higher than that in populations in either region of the native range of $B$. tectorum (tables 2,6 ). This diversity is likely a genetic consequence of multiple introductions from genetically 


\section{Table 6}

Measures of Genetic Diversity and Structure for Bromus tectorum in the Central United States (U.S.), Other Areas of North America, and Its Eurasian Native Range

\begin{tabular}{lcrccccccl}
\hline Region & Populations & \multicolumn{1}{c}{$N$} & $A$ & $\% P$ & $H_{\exp }$ & $H_{\text {obs }}$ & $H_{\mathrm{T}}$ & $G_{\mathrm{ST}}$ & Reference \\
\hline Central U.S. & 60 & 1942 & 1.05 & 4.73 & .014 & .00003 & .187 & .582 & This study \\
Eastern U.S. & 38 & 1248 & 1.01 & 1.05 & .002 & .0000 & .075 & .560 & Bartlett et al. 2002 \\
Midcontinental U.S. & 54 & 1624 & 1.04 & 4.07 & .009 & .0002 & .084 & .290 & Schachner et al. 2008 \\
Western U.S. & 50 & 1830 & 1.05 & 5.36 & .015 & .0000 & .132 & .617 & Novak et al. 1991 \\
Eastern Canada & 16 & 495 & 1.05 & 5.00 & .013 & .0003 & .265 & .447 & Valliant et al. 2007 \\
Western Canada & 44 & 1397 & 1.03 & 3.91 & .012 & .00005 & .131 & .316 & Valliant et al. 2007 \\
Europe & 39 & 1246 & 1.02 & 1.64 & .005 & .0001 & .069 & .656 & Novak and Mack 1993 \\
Southwest Asia & 12 & 484 & 1.04 & 3.67 & .005 & .002 & .201 & .735 & Novak and Mack 1993 \\
\hline
\end{tabular}

Note. $N=$ number of individuals sampled from each region. All other abbreviations are as given in tables 2 and 3 .

structured source populations (Novak and Mack 2005; Kolbe et al. 2007a, 2007b, 2008; Ficetola et al. 2008; Suarez and Tsutsui 2008; Novak 2011). The large percentage of populations in our study region that consist of two or more multilocus genotypes $(53.3 \%)$ suggests that many populations in this region, and elsewhere in North America (Novak et al. 1991; Valliant et al. 2007; Schachner et al. 2008), are genetic admixtures (see below).

\section{Population Differentiation}

With high propagule pressure, introduced populations may consist of admixtures of genotypes from different native range populations, and the proportion of genetic diversity partitioned among introduced populations could decrease relative to that in the native range (Brown and Marshall 1981; Barrett and Husband 1990; Kolbe et al. 2004; Novak and Mack 2005). Like B. tectorum populations in other parts of North America, these central U.S. populations possess less genetic structure $\left(G_{\mathrm{ST}}=0.582\right)$ than do either European populations $\left(G_{\mathrm{ST}}=0.656\right)$ or southwest Asian populations $\left(G_{\mathrm{ST}}=0.735\right.$; tables 3, 6). Higher levels of within-population genetic diversity and lower genetic structure among populations, compared with native populations, likely further reflect multiple introductions into North America and high rates of gene flow, via seed dispersal, during subsequent range expansion. Furthermore, interregional differences in genetic diversity and structure among North American populations (table 6) may reflect different degrees of propagule pressure during introduction and range expansion.

Populations within and among subregions in the central U.S. are genetically similar (table 4), suggesting that the grass's regional introduction dynamics and pattern of spread are also similar. The UPGMA diagram (fig. 3) graphically illustrates the lack of clustering of populations by geographic subregion; most groups contain populations drawn from at least three and usually all four subregions. The population at Daylight-Earle, IN, the most genetically differentiated population in our study region, is an exception. The high genetic similarity among populations from the central U.S. is consistent with results for other populations throughout the introduced range of B. tectorum in North America (Novak et al.
1991; Bartlett et al. 2002; Valliant et al. 2007; Schachner et al. 2008).

\section{Invasion of Bromus tectorum in the Central U.S.}

High propagule pressure and recombination among genotypes that were allopatric in the native range (Schierenbeck and Ellstrand 2009; Simberloff 2009) could lead to local adaptation (phenotypic evolution) and invasiveness in the introduced range (Maron et al. 2004; Lavergne and Molofsky 2007; Novak 2007; Colautti et al. 2009; Keller et al. 2009; $\mathrm{Xu}$ et al. 2010). Propagule pressure has likely facilitated the invasion of B. tectorum in the central U.S. by contributing to an increase in genetic diversity within populations of this region. In addition, a potentially novel, recombinant genotype $(M d h-2 b, M d h-3 b$, Pgm-1a \& Pgm-2a) in the central U.S. may signal postimmigration evolution. Although the possibility that this multilocus genotype was introduced directly from the native range cannot yet be ruled out, its occurrence in three central populations provides a future opportunity to study the fitness of a recombinant genotype in a predominantly selfing species. Multiyear analysis of these populations could reveal this genotype's rate of expansion in the field, thereby providing land managers with an early warning of a newly created, aggressive genotype. The detection of such low-frequency events, which may contribute to an acceleration of the invasion of B. tectorum in the central U.S., is possible only through detailed, regional population genetic analyses (Muirhead et al. 2008; Novak and Rausch 2009; Novak 2011).

\section{Acknowledgments}

We thank Nancy Mack and Lynda Leppert for invaluable assistance in obtaining seed collections of these populations; Jim Smith and three anonymous reviewers for constructive comments that improved the manuscript; Kelly Burdon, Zana Delic, and Heather Lynn Lindon for laboratory assistance; Rich Scott and Michael Davis for assistance in the preparation of the manuscript; and Dax Mickelson, Carla Stern, Ana Novak, Simeon Novak, and Maria Novak for encouragement and support. Funding for this research was provided by Boise State University and the Idaho Army National Guard. 


\section{Literature Cited}

Barrett SCH, BC Husband 1990 The genetics of plant migration and colonization. Pages 254-277 in AHD Brown, MT Clegg, AL Kahler, BS Weir, eds. Plant population genetics, breeding and germplasm resources. Sinauer, Sunderland, MA.

Barrett SCH, BJ Richardson 1986 Genetic attributes of invading species. Pages 21-33 in RH Groves, JJ Burdon, eds. Ecology of biological invasions: an Australian perspective. Cambridge University Press, Cambridge.

Barrett SCH, JS Shore 1989 Isozyme variation in colonizing plants. Pages 106-126 in DE Soltis, PS Soltis, eds. Isozymes in plant biology. Dioscorides, Portland, OR.

Bartlett E, SJ Novak, RN Mack 2002 Genetic variation in Bromus tectorum (Poaceae): differentiation in the eastern United States. Am J Bot 89:602-612.

Brown AHD, DR Marshall 1981 Evolutionary changes accompanying colonization in plants. Pages 351-363 in GG Scudder, JL Reveal, eds. Evolution today: proceedings of the Second International Congress of Systematic and Evolutionary Biology. Carnegie Mellon University Press, Pittsburgh.

Cochrane WW 1993 The development of American agriculture: a historical analysis. University of Minnesota Press, Minneapolis.

Colautti RI, IA Grigorovich, HJ MacIssac 2006 Propagule pressure: a null model for biological invasions. Biol Invasions 8:1023-1037.

Colautti RI, HJ MacIsaac 2004 A neutral terminology to define "invasive" species. Divers Distrib 10:135-141.

Colautti RI, JL Maron, SCH Barrett 2009 Common garden comparisons of native and introduced plant populations: latitudinal clines can obscure evolutionary inferences. Evol Appl 2:187-199.

Dlugosch KM, IM Parker 2008 Founder events in species invasions: genetic variation, adaptive evolution, and the role of multiple introductions. Mol Ecol 17:431-449.

Ficetola GF, A Bonin, C Miaud 2008 Population genetics reveals origin and number of founders in a biological invasion. Mol Ecol 17:773-782.

Flint-Garcia SA, JM Thornsberry, ES Buckler IV 2003 Structure of linkage disequilibrium in plants. Annu Rev Plant Biol 54:357374.

Gonçalves da Silva A, JR Eberhard, TF Wright, ML Avery, MA Russello 2010 Genetic evidence for high propagule pressure and long-distance dispersal in monk parakeet (Myiopsitta monachus) invasive populations. Mol Ecol 19:3336-3350.

Haites EF, J Mak, GM Walton 1975 Western river transportation: the era of early internal development, 1810-1860. Johns Hopkins University Press, Baltimore.

Hayes KR, SC Barry 2008 Are there any consistent predictors of invasion success? Biol Invasions 10:483-506.

Kao RH, CS Brown, RA Hufbauer 2008 High phenotypic and molecular variation in downy brome (Bromus tectorum). Invasive Plant Sci Manag 1:216-225.

Keller SR, DR Sowell, M Neiman, LM Wolfe, DR Taylor 2009 Adaptation and colonization history affect the evolution of clines in two introduced species. New Phytol 678-690.

Kolar CS, DM Lodge 2001 Progress in invasion biology: predicting invaders. Trends Ecol Evol 16:199-204.

Kolbe JJ, RE Glor, LR Schettino, AC Lara, A Larson, JB Losos 2004 Genetic variation increases during biological invasion by a Cuban lizard. Nature 431:177-181.

— 2007a Multiple sources, admixture, and genetic variation in introduced Anolis lizard populations. Conserv Biol 21:16121625 .

Kolbe JJ, A Larson, JB Losos 2007b Differential admixture shapes morphological variation among invasive populations of the lizard Anolis sagrei. Mol Ecol 16:1579-1591.
Kolbe JJ, A Larson, JB Losos, K de Queiroz 2008 Admixture determines genetic diversity and population differentiation in the biological invasion of a lizard species. Biol Lett 4:434-437.

Lavergne S, J Molofsky 2007 Increased genetic variation and evolutionary potential drive the success of an invasive grass. Proc Natl Acad Sci USA 104:3883-3888.

Layne JN 1997 Nonindigenous mammals. Pages 157-186 in D Simberloff, DC Schmitz, TC Brown, eds. Strangers in paradise. Island, Washington, DC.

Lindroth CH 1957 The faunal connections between Europe and North America. Wiley, New York.

Lockwood JL, P Cassey, T Blackburn 2005 The role of propagule pressure in explaining species invasions. Trends Ecol Evol 20:223228.

Long JL 1981 Introduced birds of the world: the worldwide history, distribution and influence of birds introduced to new environments. Universe Books, New York.

Longman OS, WG Smith 1936 Investigation of the prevalence and distribution of cheat grass in southern Alberta. Alberta Department of Agriculture, Edmonton.

Lyon HL 1927 Exotic trees in Hawaii. Hawaii Plant Rec 31:63-169.

Mack RN 1981 Invasion of Bromus tectorum L. into western North America: an ecological chronicle. Agro-Ecosystems 7:145-165.

1996 Predicting the identity and fate of plant invaders: emergent and emerging approaches. Biol Conserv 78:107-121.

2000 Cultivation fosters plant naturalization by reducing environmental stochasticity. Biol Invasions 2:111-122.

Mack RN, D Simberloff, WM Lonsdale, H Evans, M Clout, FA Bazzaz 2000 Biotic invasions: causes, epidemiology, global consequences, and control. Ecol Appl 10:689-710.

Maron JL, M Vila, R Bommarco, S Elmendorf, P Beardsley 2004 Rapid evolution of an invasive plant. Ecol Monogr 74:261-280.

McKone MJ 1985 Reproductive biology of several bromegrasses (Bromus): breeding system, pattern of fruit maturation, and seed set. Am J Bot 72:1334-1339.

Meinig DW 1995 The shaping of America: a geographical perspective on 500 years of history. Vol 3. Transcontinental America, 1850-1915. Yale University Press, New Haven, CT.

Muhlenberg H 1793 Index florae lancastriensis. Trans Am Philos Soc Phila 3:157-184.

Muirhead JR, DK Gray, DW Kelly, SM Ellis, DD Heath, HJ MacIsaac 2008 Identifying the source of species invasions: sampling intensity vs. genetic diversity. Mol Ecol 17:1020-1035.

Nei M 1973 Analysis of gene diversity in subdivided populations. Proc Natl Acad Sci USA 70:3321-3323.

$1977 \mathrm{~F}$-statistics and analysis of gene diversity in subdivided populations. Ann Hum Genetics 41:225-233.

- 1978 Estimation of average heterozygosity and genetic distance from a small number of individuals. Genetics 89:583-590.

Nei M, T Maruyama, R Chakraborty 1975 Bottleneck effect and genetic variability in populations. Evolution 29:1-10.

Novak SJ 1990 Multiple introduction and founder effects in Bromus tectorum L.: an analysis of Eurasian and North American populations. PhD diss. Washington State University, Pullman.

2007 The role of evolution in the invasion process. Proc Natl Acad Sci USA 104:3671-3672.

2011 Geographic origins and introduction dynamics. Pages 273-280 in D Simberloff, M Rejmánek, eds. Encyclopedia of biological invasions. University of California Press, Berkeley.

Novak SJ, RN Mack 1993 Genetic variation in Bromus tectorum (Poaceae): comparison between native and introduced populations. Heredity $71: 167-176$. 
2001 Tracing plant introduction and spread: genetic evidence from Bromus tectorum (cheatgrass). BioScience 51:114-122.

2005 Genetic bottlenecks in alien plant species: influence of mating systems and introduction dynamics. Pages 201-228 in DF Sax, JJ Stachowicz, SD Gaines, eds. Species invasions: insights into ecology, evolution and biogeography. Sinauer, Sunderland, MA.

Novak SJ, RN Mack, DE Soltis 1991 Genetic variation in Bromus tectorum (Poaceae): population differentiation in its North American range. Am J Bot 78:1150-1161.

Novak SJ, RN Mack, PS Soltis 1993 Genetic variation in Bromus tectorum (Poaceae): introduction dynamics in North America. Can J Bot 71:1441-1448.

Novak SJ, JH Rausch 2009 Use of field surveys, distributional data and genetic analyses to monitor alien species: Taeniatherum caputmedusae as an example of the approach. Neobiota 8:169-182.

Pierson EA, RN Mack 1990 The population biology of Bromus tectorum in forests: distinguishing the opportunity for dispersal from environmental restriction. Oecologia 84:519-525.

Pimentel D, R Zuniga, D Morrison 2005 Update on the environmental and economic costs associated with alien-invasive species in the United States. Ecol Econ 52:273-288.

Ramakrishnan AP, SE Meyer, DJ Fairbanks, CE Coleman 2006 Ecological significance of microsatellite variation in western North American populations of Bromus tectorum. Plant Species Biol 21: 61-73.

Rejmánek M, DM Richardson, SI Higgins, MJ Picairn, E Grotkopp 2005 Ecology of invasive plants: state of the art. Pages 104-161 in HA Mooney, RN Mack, JA McNeely, LE Neville, PJ Schei, JK Waage, eds. Invasive alien species, a new synthesis. Island, Washington, DC.

Richardson DM, P Pyšek 2006 Plant invasions: merging the concepts of species invasiveness and community invisibility. Prog Phys Geogr 30:409-431.

Ridley HN 1930 The dispersal of plants throughout the world. Reeve, Kent, UK.

Ross KG, DD Shoemaker 2008 Estimation of the number of founders of an invasive pest insect population: the fire ant Solenopsis invicta in the USA. Proc R Soc B 275:2231-2240.

Ruiz GM, JT Carlton 2003 Invasion vectors: a conceptual framework for management. Pages 459-504 in GM Ruiz, JT Carlton, eds. Invasive species: vectors and management strategies. Island, Washington, DC.

Sakai AK, FW Allendorf, JS Holt, DM Lodge, J Molofsky, KA With, S Baughman, et al 2001 The population biology of invasive species. Annu Rev Ecol Syst 32:305-332.

Sala OE, FS Chapin III, JJ Armesto, E Berlow, J Bloomfield, R Dirzo, E Huber-Sanwald, et al 2000 Global diversity scenarios for the year 2100. Science 287:1770-1774.

Schachner LJ, RN Mack, SJ Novak 2008 Bromus tectorum (Poaceae) in midcontinental United States: population genetic analysis of an ongoing invasion. Am J Bot 95:1584-1595.

Schierenbeck KA, NC Ellstrand 2009 Hybridization and the evolution of invasiveness of plants and other organisms. Biol Invasions 11:1093-1105.
Shaw RE 1993 Canals for a nation: the canal era in the United States, 1790-1860. University Press of Kentucky, Lexington.

Simberloff D 1986 Introduced insects: a biogeographic and systematic perspective. Pages 3-26 in HA Mooney, JA Drake, eds. Ecology of biological invasions of North America and Hawaii. Springer, New York.

2009 The role of propagule pressure in biological invasions. Annu Rev Ecol Evol Syst 40:81-102.

Soltis DE, CH Haufler, DC Darrow, GJ Gastony 1983 Starch-gel electrophoresis of ferns: a compilation of grinding buffers, gel and electrode buffers, and staining schedules. Am Fern J 73:9-27.

Squirrell J, PM Hollingsworth, RM Bateman, JH Dickson, MHS Light, M MacConaill, MC Tebbitt 2001 Partitioning and diversity of nuclear and organelle markers in native and introduced populations of Epipactis helleborine (Orchidaceae). Am J Bot 88:1409-1418.

Suarez AV, ND Tsutsui 2008 The evolutionary consequences of biological invasions. Mol Ecol 17:351-360.

Swofford DL, RB Selander 1981 BIOSYS-1: a FORTRAN program for the comprehensive analysis of electrophoretic data in populationgenetics and systematics. J Hered 72:281-283.

Tsutsui ND, AV Suarez, DA Holway, TJ Case 2000 Reduced genetic variation and the success of an invasive species. Proc Natl Acad Sci USA 97:5948-5953.

Upadhyaya MK, R Turkington, D Mcllvride 1986 The biology of Canadian weeds. 75. Bromus tectorum L. Can J Plant Sci 66:689-709.

Valliant MT, RN Mack, SJ Novak 2007 Introduction history and population genetics of the invasive grass Bromus tectorum (Poaceae) in Canada. Am J Bot 94:1156-1169.

Veltman CJ, S Nee, MJ Crawley 1996 Correlates of introduction success in exotic New Zealand birds. Am Nat 147:542-557.

von Holle B, D Simberloff 2005 Ecological resistance to biological invasions overwhelmed by propagule pressure. Ecology 86:32123218.

Wares JP, AR Hughes, RK Grosberg 2005 Mechanisms that drive evolutionary change: insights from species introductions and invasions. Pages 229-257 in DF Sax, JJ Stachowicz, SD Gaines, eds. Species invasions: insights into ecology, evolution and biogeography. Sinauer, Sunderland, MA.

Watterson GA 1984 Allele frequencies after a bottleneck. Theor Popul Biol 26:387-407.

Wilcove DS, D Rothstein, J Dubow, A Phillips, E Losos 1998 Quantifying threats to imperiled species in the United States. BioScience 48:607-615.

Williamson MH, A Fitter 1996 The characters of successful invaders. Biol Conserv 78:163-170.

Workman PL, JD Niswander 1970 Population studies on Southwestern Indian tribes. 2. Local genetic differentiation in Papago. Am J Hum Genet 22:24-49.

Xu C-Y, MH Julien, M Fatemi, C Girod, R van Klinken, CL Gross, SJ Novak 2010 Phenotypic divergence during the invasion of Pyla canescens in Australia and France: evidence for selection-driven evolution. Ecol Lett 13:32-44.

Yensen DL 1981 The 1900 invasion of alien plants into southern Idaho. Great Basin Nat 41:176-183. 